\title{
Gerhard Ebeling oor geloof
}

\section{Author:}

Gafie van Wyk ${ }^{1}$

\section{Affiliation:}

${ }^{1}$ Department of Church History and Polity University of Pretoria, South Africa

Project leader: A. Ungerer (HTK) Project number: 82329542

\section{Description:}

This research is affiliated with the Reformed Theological College, Faculty of Theology, University of Pretoria.

\section{Corresponding author:} Gafie van Wyk, gafievw@mweb.co.za

\section{Dates:}

Received: 07 Dec. 2015 Accepted: 25 Jan. 2016 Published: 29 July 2016

How to cite this article: Van Wyk G., 2016, 'Gerhard Ebeling oor geloof', HTS Teologiese Studies/ Theological Studies 72(3), a3279. http://dx.doi. org/10.4102/hts.v72i3.3279.

\section{Copyright:}

(C) 2016. The Authors. Licensee: AOSIS. This work is licensed under the Creative Commons Attribution License.

\section{Read online:}

Gerhard Ebeling on faith. Gerhard Ebeling (1912-2001), not only the foremost Luther researcher of the previous century but also one of the most prominent contributors to protestant theology during that period, wrote extensively about faith throughout his long and productive life as a professional theologian. He learnt from Luther that discerning judgement in the differentiation of related matters forms the basis of all sound theology. Applying this insight to his own thought, he reflects on the development of the phenomenon of faith in the Old Testament community and early Christianity and the formalisation of the concept for use in the domain of religious studies. He defends the argument that Christian faith is not only faith in Jesus as the Christ and Lord but also that Jesus, and $\mathrm{He}$ only, is the founder and perfecter of faith. The concept of faith is also explored by Ebeling in relation to love, life and reason. The article concludes with a critical evaluation of Ebeling's contribution in guiding us to witness authentically about our own faith in Jesus Christ within our own situation and against the background of the problems it poses for believing in Christ.

\section{Ebeling se teologiese benadering}

Ebeling se wetenskaplike skryfwerk is in sommige gevalle die opskrifstelling van detailnavorsing, ondersteun deur ' $n$ uitgebreide sisteem voetnotas wat na die toepaslike bronnemateriaal verwys, maar in ander gevalle kom 'n deurwinterde selfstandige denker aan die woord wat nouliks na ander skrywers se werk verwys. Die meeste van sy toegespitste Luther-navorsing berus byvoorbeeld op intensiewe bronnestudie, maar in sy driebandige Dogmatik des christlichen Glaubens $^{1}$, daarenteen, word selde na enige bronne ter ondersteuning van sy eie standpunte verwys. Anders as baie ander teoloë van sy tyd stel hy nie daarin belang om algemene teologiese inligting - soos verwoord deur bekende voorgangers of tydgenote - aan te haal of om die standpunte van ander bloot weer te gee en te bespreek nie. Waar hy wel op die insigte van ander terugval, soos met Luther wat dikwels aangehaal word, herhaal hy nie net klakkeloos wat geskryf is nie, maar gebruik hy die gedagtes van die ander as aanleiding om selfstandig verder na te dink oor die saak wat ter tafel is. Polemiek oor ander teoloë se standpunte vorm nie deel van Ebeling se werk nie en direkte teologiese debat met ander is skaars in sy oeuvre. Ebeling dink radikaal krities met ' $n$ fyn hermeneutiese aanvoeling vir die lewe as denkkonteks eerder as dat hy die een of ander sisteem of denkkonstruksie as vertrekpunt neem, en hy is altyd gefokus op die saak wat ter sprake is.

Wat lê ten grondslag van Ebeling se denk- en skryfstyl? Wat maak dat sy skryfwerk teologie is en wat weerhou dit daarvan om pseudoteologie of eintlik maar net berigte oor teologie te wees? Ebeling vind die vertrekpunt vir sy teologiese benadering by Luther: 'Wie weet hoe om goed te kan onderskei, is 'n goeie teoloog'2 (Beutel 2006:327-329; Ebeling 1988:219, outeur se eie vertaling Schlögel 1992:230). Ebeling deel Luther se standpunt volmondig dat goeie onderskeidingsvermoë die grondslag van teologiese denke vorm. In die teologiebeoefening kom dit daarop neer om goeie teologiese oordeel aan die dag te lê. In teologiese nadenke gaan dit in terme van die Kantiaans-geykte onderskeidings nie oor die regte gebruik van die rede (Vernunft) nie, maar om goeie onderskeidingsvermoë (Urteilskraft). ${ }^{3}$ In teologiese nadenke kan dit immers nie om die outonome gebruik van die rede en die wilsbesluite van mense gaan nie (want as gelowige buig

1.Ebeling (1979a:vii, 6) stel dit duidelik dat hy met hierdie werk selfstandig rekenskap van sy Christelike geloof wil gee en dat die samehangende uitsprake van sy geloofsverantwoording as sodanig oortuigingskrag moet hê. Hy wil die lesers van die driebandige werk saamneem op ' $n$ omvattende teologiese denkreis om hulle sodoende te oortuig om self ook selfstandig en selfkrities oor geloof te besin met die doel om groter sekerheid te kry oor hulle eie geloofsgronde (Ebeling 1979a:ix). Hy is oortuig dat die gebrek aan omvangryke verwysings na vakliteratuur en die vermyding van polemiese opmerkings nie enige afbreek doen aan die wetenskaplike omvangryke verwysings na vakliteratuur en die
kwaliteit van die werk nie (Ebeling 1979a:vii, 5).

2.Wer das gut zu unterscheiden weiß, ist ein guter Theologe. Ebeling([1967] 1971b:327) stel dat die innerlike rypheid van die regte geloof Urteilsfähigkeit (die vaardigheid om goed te oordeel) veronderstel.

3.Ebeling (1989:462) maan egter ook dat onderskeidingsvermoë nie met die praktiese rede verwar moet word nie. Die praktiese rede beslis oor afsonderlike dade of sake, maar onderskeidingsvermoë fokus op die mens as sodanig - die persoon wat deur ander geoordeel word en die konteks waarbinne dié persoon lewe.

Note: Dr G.M.J. (Gafie) van Wyk is research associate of Dr Wim Dreyer in the Department of Church History and Polity, Faculty of Theology, University of Pretoria, Pretoria, South Africa. 
die teoloog voor die wil van God), maar wel om onderskeidings wat die mens met gewetensvryheid tref. Die teoloog moet self aan die woord kom, maar dan as 'n mens wat coram Deo et hominibus (voor God en die mense) rekenskap gee (Ebeling 1979a:5). Ook in hierdie verband laat Ebeling hom deur Luther lei: 'Luther verdedig die onvryheid van die wil ter wille van die vryheid van die gewete ${ }^{\prime 4}$ (Ebeling 2006a:248; outeur se eie vertaling ). Anders as die heersende opvatting, verstaan Ebeling (1983c:189, 1989:453, 461, 2006a:302-303) die gewete egter nie as normatiewe bewussynsinhoude of outonome oordeelsfunksies van die mense self nie, maar (soos Luther) dat daar relasioneel altyd op mense in hulle persoon-wees aanspraak gemaak word en dat hulle aan oordeel uitgelewer is omdat hulle voortdurend aangespreek word (Ebeling 1969b:94, 97, 1989:459; Schlögel 1992:231). Goeie onderskeidingsvermoë behels die fundamentele onderskeiding van sake sonder dat in growwe antiteses verval word, omdat die sake wat onderskei word deur 'n simul, 'n tegelykheid, aan mekaar verbonde bly. Ebeling (1975a:247; outeur se eie vertaling) skryf: '[Want] verstaan is begrip van samehang'. ' $n$ Saak wat los van enige samehang beredeneer word, skep die indruk van belangeloosheid. Die fundamentele onderskeidings wat in samehang met mekaar teologies oordink moet word en waaroor Ebeling dit hier het, is byvoorbeeld dié tussen woord en daad, filosofie en teologie, letter en Gees, wet en evangelie, die tweevoudige gebruik van die wet, persoon en werk, geloof en liefde, die ryk van Christus en die ryk van die wêreld, vryheid en onvryheid, die verborge en die openbarende God.

Die paar opmerkings oor Ebeling se teologiese benadering as die vermoë om goeie oordeel in die onderskeiding van sake aan die dag te lê, dien nie net as formele prolegomena tot wat volg nie, want dit het, wat die geloofstema betref, ook saaklike relevansie. Dit blyk duidelik uit woorde van Luther ([1529] 1985:9) se uitleg van die eerste gebod in sy Katechismus van 1529 wat Ebeling as vertrekpunt neem:

Is [jou] geloof en vertroue reg, dan is jou God ook reg, en omgekeerd: indien die vertroue vals en onjuis is, is die regte God ook nie teenwoordig nie. Gevolglik hoort die twee tesame, geloof en God. ${ }^{6}$ (Ebeling 1975a:260-261; outeur se eie vertaling)

Geloof het altyd betrekking op sowel God as die mensdom en die wêreld (Ebeling 1975a:260-261).

\section{Luther vertrete die Unfreiheit des Willens um der Freiheit des Gewissens willen. \\ 5.Denn Verstehen ist Erfassen von Zusammenhang. Ebeling ([1981] 1983f:85) stel die saak soos volg: Denken heißt Unterscheidungen wahrnehmen, um Zusammenhänge zu erfassen. Hy verduidelik ook die saak verder soos volg: Die Unterscheidungen $z u$ erfassen. Hy verduidelik ook die saak verder soos volg. Die Unterscheidungen werden vielmehr nun erst richtig wahrgenommen und gewahrt. Sie dienen nicht wie logische Unterscheidungen zur Auflösung von Problemen, sondern sollen die realen Gegensätze so verschärfen, daß sie unverfälscht zum Austrag kommen. Daraus entsteht eine Vielzahl von Dualitäten, ... (Ebeling 1983g:3). Ebeling (1983e:134- 135) verduidelik sy intensie met die begrip Fundamentalunterscheidung ook soos volg: Gewiß ist auf die unterschiedliche Modalität der Relationen zwischen den opposita zu achten. Aber da es sich nicht blo $\beta$ um die Verhältnisbestimmung statischer Größen zu einander handelt, sondern um Lebensvorgänge des Widersprechens, des Versprechens und des Entsprechens, treffen das Widereinander und das Dennoch-Miteinander so zusammen, daß auf diese Weise das Leben selbst und das Dennoch-Miteinander so zusammen, daß auf diese Weise das Leben selbst getroffen wird, während es sich einem abstrahierenden Denken entzieht. Kyk ook in bespreking van die aangeleentheid deur Ebeling (1981:273-281) in wat hyself (Ebeling 1981:282)'n exkursartigen Skizze noem.}

6.Sind Glaube und Vertrauen recht, so ist Dein Gott recht; und umgekehrt: wo das Vertrauen falsch und unrecht ist, da ist auch der rechte Gott nicht. Denn die zwe hören zusammen, Glaube und Gott.

\section{Die fenomeen geloof}

Geloof is nie net 'n idee of ' $n$ moontlikheid nie, maar ' $n$ gegewendheid.Geloof is nie'n subjektiewe veronderstelling wat gepostuleer word deur hulle wat oor geloof nadink of rekenskap daarvan gee nie, maar dit is 'n gegewendheid wat nie ontken kan word nie en veral as godsdienstige fenomeen uitdrukking vind (Ebeling 1979a:79). Geloof is in alle gevalle waar dit ter sprake kom 'n lewensfenomeen - dan egter nie net as ' $n$ fenomeen wat op die lewe betrekking het nie, maar ook as dié een wat aanspraak maak om aan die lig te bring wat ware lewe eintlik behels. Geloof gaan oor niks anders nie as die werklikheid self (Ebeling 1967b:397). Wie rekenskap van geloof wil gee, moet daarom die verband tussen geloof en lewe deurlopend in die oog hou (Ebeling 1979a:79-80). Geloof kan egter eers met betrekking tot die lewe bespreek word wanneer uitgeklaar is wat die fenomeen geloof beteken.

Wanneer Ebeling (1979a:80-81) die fenomeen geloof beskryf, vind hy sy vertrekpunt nie in die godsdiensfenomenologie nie, maar in die Christelike geloof. Hierdie benadering word nie gekies as gevolg van enige vooroordeel ten gunste van die Christendom teenoor ander godsdienste nie, maar as gevolg van spesifieke historiese en taalverwante sake wat verband hou met die fenomeen. Ebeling (1975b:229, 1979a:81, 1983b:60) dui aan dat die gebruik van die begrip geloof as ' $n$ welbekende term in godsdienstige taal bepaalde historiese wortels het wat in die Ou Testament terug te vind is. In die Ou Testament het die begrip egter nog nie 'n prominente rol gespeel nie. Die vroegste gebruik daarvan vind ons in Jesaja 7:9 (Glo julle nie, sal julle nie voortbestaan nie $^{7}$ ) en Genesis 15:6 (Abraham het die Here geglo en Hy het hom dit as geregtigheid toegereken). Geloof beteken in hierdie gevalle dat die gelowiges op die Betroubare vertrou. ${ }^{8}$ Hoewel die gebruiksfrekwensie van die Griekse begrippe pisteuein (om te glo) en pistis (geloof) in die Hellenistiese Diasporajodedom $^{9}$ toegeneem het, word dit eers in die Nuwe Testament as die vernaamste verhoudingsbegrippe met betrekking tot God gebruik (Ebeling 1971a:302). Dit word daar gebruik om uitdrukking te gee aan die volgelinge van Jesus se verhouding met Hom (en by implikasie met sy Vader). Mettertyd speel die begrip so ' $n$ belangrike rol dat daar eenvoudig na die Christene as gelowiges verwys word (Ebeling 1979a:81). Vir sy verdere argumentvoering is die waarneming vir Ebeling (1979a:81, 1975b:229-230) van belang dat, sintakties gesien, die preposisionele verbinding 'glo aan' of letterlik 'glo in' met die akkusatief vir die eerste keer in die Nuwe Testament gebruik word. Voorheen is die begrip geloof net gebruik om aan te dui dat iemand geglo is of dat iets geglo is, of 'n kombinasie van die twee gedagtes. Uit die tydperk voor die Nuwe

7.Die Hebreeuse werkwoorde wat ek hier met 'glo' en 'voortbestaan' vertaal, hou verband met die woord 'amen' wat ons ook in Afrikaans gebruik.

8.Ebeling ([1958] 1967c:210-220) behandel wel die geloofsbegrip in die Ou Testament omvattend, maar'n bespreking daarvan val buite die bestek van hierdie artikel.

9.Ebeling ([1958] 1967c:221-228) gee ook uitvoerig aandag aan die geloofsbegrip soos in die Hellenistiese tyd gebruik. 
Testament vind ons nie enige voorbeelde ${ }^{10}$ van die uitsluitlike oriëntering van die geloof aan 'n menslike persoon nie. Dieselfde geld ook vir die genetiefverbinding (genitivus objectious) van die begrip geloof met die naam Jesus Christus. Wanneer die geloofsbegrip in 'n absolute sin gebruik word, is die betrekking daarvan op Jesus Christus altyd ' $n$ veronderstelling. In die Nuwe Testament word geloof op so 'n wyse in die sentrum geplaas dat dit die wese van die Christelike lewe uitmaak. Die geloof word voortdurend op Jesus gerig, ${ }^{11}$ omdat dit deur Hom gewek is en deur Hom in stand gehou word (Gal 3:23, 25). Jesus is nie alleen die onderwerp van geloof nie, maar ook die bron en die grond daarvan (Ebeling 1967c:204, 245, 1981:239, 1989:450). Volgens Hebreërs 12:2 is Jesus die Grondlegger en die Voleinder van die geloof (Ebeling 1967c:206, 1975b:230, 1979a:82).

Geloof het reg deur die geskiedenis van die kerk 'n dominante begrip gebly. In ekstreme gevalle was gelowiges bereid om in die naam van geloof 'n marteldood te sterf. Hoewel geloof in die Nuwe Testament feitlik uitsluitlik op Jesus betrekking het, ${ }^{12}$ vind daar met verloop van tyd 'n trinitariese klemverskuiwing ten opsigte van geloofsverstaan in die kerk plaas sodat geloof later verstaan word as geloof in die Vader, die Seun en die Heilige Gees, of gewoon as geloof in God (Van Staden 2015:16). Hierdie verskuiwing bring in der waarheid geen saaklike verandering teweeg nie, omdat geloof in Jesus Christus in die Nuwe Testament eo ipso op die gelowiges se verhouding met God betrekking het. Deur Jesus word God ervaar (Ebeling 1975d:243, 1979a:82).

Elke gelowige moet self glo, en iemand anders kan, wanneer dit by geloof kom, nie vir die gelowige intree nie (Ebeling 1975b:234, 1981:288). 'n Mens kan net self bely: credo (ek glo). Geloof en die belydenis daarvan hoort onlosmaaklik saam. Die feit dat elke gelowige self glo, staan nie in teenspraak met die feit dat hy of sy saam met ander gelowiges as lid van die kerk glo nie (Van Wyk 2012:7). Wie credo bely, kan ook saam met die kerk credimus (ons glo) bely. Selfs wanneer geloof tot fides quae creditur (geloofsinhoud, wat geglo word) geobjektiveer word, kan dit steeds nie van fides qua creditur (geloofsdaad, om te glo) losgemaak word nie. Dat die individu self glo en self geloof bely, beteken nie dat geloof ' $n$ prestasie van die mens is nie, want geloof word deur die mens as die ontvanger daarvan bely. Geloof is nie menslike werk nie, maar geskenkte genade van God wat deur mense ontvang word (Ebeling 1971a:305, 1979a:82-83, 1989:441; Van Wyk 2015:3).

10.Dat Ebeling in sy argumentvoering 'n aanname maak op grond daarvan dat dokumentêre bewysstukke ontbreek om die aanname te kan weerlê, bring mee dat die standpunt wat hy stel net voorlopig kan wees, en daarom ook net relatief seke is, maar dit verander niks aan die wese van sy betoog dat die begrip 'geloof' in die Christedom 'n nuwe en voorheen ongekende toegespitste gebruiksmoontlikheid gevind het wat dit 'n kernbegrip, of dalk selfs die vernaamste begrip, van die Christelike geloof of woordeskat gemaak het nie.

11.Ebeling (1995:128-129) verduidelik die konsekwensie van hierdie uitgangspunt soos volg: Wenn wir doch das glauben, daß unser Sein so festgebunden ist an Jesu Sein! ... Dann wäre das, was wir von Christus bekennen, kein bloßer Glaubensartikel, sondern das Lebensgesetz, unter dem wir stehen.

12.Bultmann (1968:210) wys daarop dat net twee moontlike gevalle in die Nuwe Testament geloof as ' $n$ relasie met God aandui, naamlik 1 Petrus 1:21 en Johannes $14: 1$
Geloofsuitsprake het iets te sê. Geloof kom primêr deur die hoor van die Woord tot stand en dit leef uit die toegespreekte Woord met die gevolg dat gelowiges hulle verlaat op die Woord wat hulle aanspreek (Ebeling 1967c:214, 1991:382). Geloof as verhouding met God het altyd betrekking op die Woord wat die gelowige aanspreek. Jesus Christus is die grond van ons geloof omdat Hy as God se Woord in persoon geglo word (Ebeling 1971a:305, 1989:451, 1991:383). Ons staan egter nie in 'n onbemiddelde persoonlike verhouding met Jesus nie, maar in 'n verhouding wat deur Christelike getuienis bemiddel word. Geloof ontstaan uit die Woord en is daarom antwoord op die Woord. Die Woord wat ons provokeer om te glo, is egter ook reeds 'n geloofsuitspraak in die dubbele sin van die woord, naamlik as Woord wat geloof ten doel stel en as Woord wat in geloof gespreek word (Ebeling 1979a:83-84).

Geloof bied lewe aan elke gelowige. Geloofsuitsprake is daarom nie die blote mededeling van kennis of inligting nie, ${ }^{13}$ maar woorde wat die mens se lewensituasie ingrypend verander (Ebeling 1967c:214, 1975b:232-233). Die Woord wat 'n mens provokeer om te glo, vra om 'n beslissende antwoord, want dit handel oor die lewensbeslissende saak - die heil van die mens. Die Woord stel jou voor die alternatiewe van verlore wees of aangeneem word, van lewe in sonde of lewe deur genade, van duisternis of lig, van dood of lewe. Die Woord het soteriologiese relevansie, want die Woord verkondig nie ' $n$ doodsklagte nie, maar opstandingsvreugde (Ebeling 1979a:84).

\section{Die formalisering van die begrip geloof}

Vandag is die gebruiksmoontlikhede van die begrip geloof alreeds tot so 'n mate uitgebrei dat dit as algemene religieuse kategorie gebruik word. Indien iemand byvoorbeeld sou vra wat jou geloof is, verstaan ons dat eintlik gevra word watter godsdiens jy aanhang. In die tyd van die Ou Testament was dit egter ondenkbaar om na die verering van Baäl in terme van geloof in hom te verwys. Net so sou die verering van die keiser ook nie later as geloof in die keiser beskryf word nie. Geloof dui in die Bybel slegs die relasie met die ware, lewende God aan, en daarom word die verhoudings met ander gode nie in die Bybel as geloof beskryf nie (Ebeling 1967c:218). Die geloofsbegrip is egter sedert die opkoms van godsdienswetenskap veralgemeen, geneutraliseer en geformaliseer om as algemene religieuse kategorie te kan dien. Die gevolg was dat dit ook in die proses nivellering ondergaan het. Die begrip geloof word vandag gebruik om selfs die onnadenkende en gewetenlose oorname van vreemde idees of die aanpassing by die heersende menings of oortuigings van die omgewing aan te dui (Ebeling 1979a: 84-85).

Ebeling (1979a:85-86) verduidelik die implikasie van die formalisering van die geloofsbegrip vir ons selfverstaan aan

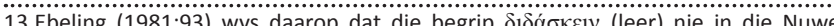
Testament gebruik word om die bekendmaking van die evangelie te beskryf nie,

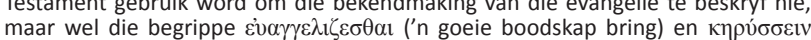
(verkondig). Hy verduidelik die rede daarvoor soos volg: Denn es wendet sich nicht (verkondig). Hy verduidelik die rede daarvoor soos volg: Denn es wendet sich nicht
an den Verstand, sondern an das Gewissen als den innersten Lebensnerv des Menschen (Ebeling 1981:93) 
die hand van die verband tussen geloof en vryheid. Vanuit 'n Christelike perspektief word 'n geloofsbeslissing as bevrydingsgebeure verstaan. Deur die geloof is die Christengelowige ' $n$ vrye heer oor alle dinge en aan niemand onderdanig nie (Luther [1520] 1983:162; Ebeling 1979a:85). 'Vir vryheid het Christus ons bevry' (Gal 5:1). In die sekulêre samelewing word die Christelike opvatting oor geloofsvryheid prysgegee ter wille van die opvatting dat elke mens vry behoort te wees om 'n eie geloof te kies. Hierdie vryheid word nie deur Christus bewerk nie, maar deur die staat aangebied en deur wetgewing verskans. Hier beteken geloofsvryheid algemene religieuse toleransie (Ebeling 1983d:106). Mense moet selfs vry wees om 'n godsdiens te kan kies wat hulle van alle persoonlike vryheid ontneem en hulle gewetensvryheid totaal en al aan bande lê. Ons weet maar alte goed dat die vryheid om 'n godsdiens van jou eie keuse te mag aanhang in werklikheid nog nie universele vryheid in die ware sin van die woord waarborg nie.

Die formalisering van die geloofsbegrip kan egter wel volgens Ebeling (1979a:86-88) teologies geregverdig word. Wanneer die Christelike tradisie sekere begrippe as instrumente aan die godsdienswetenskap en die wetenskapsgemeenskap beskikbaar maak om andersoortige fenomene in terme van interne organisasie en die dieptestruktuur daarvan te kan interpreteer, is die onderneming om hierdie begrippe te formaliseer, regverdigbaar. Met die formalisering van die geloofsbegrip het ons met so 'n geval te make. Luther ([1529] 1985:9) stel in sy uitleg van die eerste gebod onder andere dat dít waarop jy jou verlaat jou God is. Hierdie insig kan as instrument aangewend word in die algemene godsdienswetenskap. Jou geloof toon mos aan wie of wat eintlik jou god is-ook wat ander godsdienste as die Christendom betref. Die begrip geloof kan sinvol as 'n algemene godsdienswetenskaplike vakterm aangewend word. Ons moet daarom altyd duidelik onderskei in watter verband en met watter betekenis die begrip geloof in die teologie gebruik word.

\section{Geloof in Jesus Christus}

Christelike geloof het 'n spesifieke gerigtheid - per definisie verwys dit na Jesus die provokeerder, maar ook die objek van geloof (Ebeling 1975c:276, 295, 1981:168, 238, 1989:141). Die credo-uitspraak van die Symbolum Apostolicum betrek nie alleen die gelowige wat geloof bely by die belydenis wat afgelê word nie, maar bepaal ook die verband tussen die dele van die geloofsbelydenis wat na Jesus verwys as uitspraaksamehang. Wat oor Jesus bely word, geld in die geheel as geloofsuitspraak, en alleen as geloofsuitspraak is wat gesê word legitiem (Ebeling 1975a:251-252). Die teks van die Apostolicum of enige ander belydenisteks kan daarom nie geld as geloofsvoorskrif waarvan die fides quae creditur, naamlik die afsonderlike belydenisuitsprake, as objektiewe feite verstaan word wat elkeen afsonderlik histories bewys kan word nie (Ebeling 1975a:249, 1975c:282; Hempelmann 2013:188). Reeds vanuit 'n sintaktiese oogpunt is dit duidelik dat dit in die uitsprake van die tweede artikel van die Apostolicum oor 'n ondeelbare geheel handel en nie oor die som van die afsonderlike aangeleenthede wat ter sprake kom nie. In wese bely ons met die tweede artikel van die Apostolicum 'Ek glo in Jesus Christus' of selfs net 'Ek glo in Jesus'. ${ }^{14}$ Daarmee word wesentlik alles van belang uitgespreek. Alles wat verder in die tweede artikel bely word, moet as verheldering van hierdie geloofsuitspraak dien, anders is dit illegitiem. Alles wat in die tweede artikel van die Apostolicum naas die woorde 'Ek glo in Jesus' bely word, het alleen relatiewe reg in soverre dit op die sentrale uitspraak van die artikel betrekking het. Dit beteken nou nie dat die grammaties relatiewe uitbreidings in die tweede artikel van die belydenis as oorbodig verklaar word nie. Ebeling (1975a:252-253) wil slegs aantoon dat 'n additiewe neweskikking van die uitsprake in die tweede artikel nie moontlik is nie. ${ }^{15}$ Die gelowige glo byvoorbeeld nie in die maagdelike geboorte en daarnaas ook in die opstanding en ook nog in die hemelvaart of die wederkoms nie. Die gelowige glo in Jesus Christus, wat (qui) ontvang is van die Heilige Gees, gebore is uit die maagd Maria ... Die relatiewe uitbreidings in die tweede artikel het egter nie blote dekoratiewe waarde nie. Dit bied verstaanshulp oor die intensie van die artikel en dien ook as kriteria om die veragting of die vervalsing van die primêre uitspraak van die artikel teë te werk. ${ }^{16}$ Ebeling (1975a:253) wys daarop dat die samehang waaroor dit in die belydenisartikel gaan nie deur 'n idee (gedankliches Prinzip) bepaal word nie, maar deur'n historiese gebeurtenis (geschichtliches Ereignis).

Ebeling redeneer natuurlik nie bloot aan die hand van die struktuur van die Apostolicum oor geloof in Jesus nie, maar vorm sy standpunt veral op grond van die Nuwe Testament. Met ' $n$ belydenis gee ons in geloof self rekenskap oor Jesus. Volgens Markus (6:14-15; 8:27-28) het menings reeds in Jesus se tyd uiteengeloop oor wie Hy is. In die lig daarvan het Jesus toe vir sy dissipels die vraag gevra waarmee Markus by implikasie ook sy lesers konfronteer: 'Wie sê julle is Ek?' Petrus het die vraag met die belydenis 'U is die Christus' (Mark 8:29) beantwoord (Van Staden 2015:1). Binne die Hellenistiese konteks moes opnuut oor Jesus rekenskap gegee word - en hier word Hy dan as die Here (Kurios) bely (1 Kor 12:3). Gelowiges moet voortdurend in situasies wat om verantwoording vra opnuut rekenskap oor

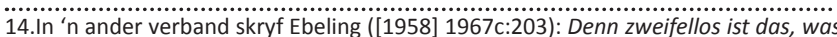
das Christsein ausmacht, der Glaube an Jesus Christus. Ebeling ([1982] 1983e:140141) stel die saak ook goed soos volg: Evangelium weist uns nicht an einen Katalog von Satzungen, sondern an die Person Jesus Christus ... Es gibt deshalb nur einen einzigen usus evangelii: den Glauben.

15.Ebeling (1979a:30-33) dui in hierdie verband ' $n$ baie belangrike verskil aan tussen Reformatoriese teologie en ortodokse Protestantse teologie (wat die uitsprake van die geloofsbelydenis vermenigvuldig), asook die verskil in Skrifverstaan die geloofsbelydenis vermenigvuldig), asook die verskil in Skrifverstaan
onderliggend aan dié twee benaderings. In Suid-Afrika verwyt ortodokse Protestante kritiese gelowiges voortdurend daarvan dat hulle ontrou sou wees aan die Reformatoriese erfenis omdat hulle nie 'n volledige kanon van 'heilsfeite' sou aanvaar nie - dit, terwyl Luther self net een kriterium gebruik het om die geloofsinhoud te toets, naamlik: 'Ob sie Christum treiben oder nicht' (Ebeling 1979a:32). Ebeling ([1975] 2012:137-138) verduidelik die saak soos volg: Jede echte Glaubensaussage ist in nuce vollständig ... Daß trotzdem ein auf seinen Zusammenhang zu bedenkendes Nebeneinander von Aussagen in Betracht zu ziehen ist, bringt der Begriff des Glaubensartikels zum Ausdruck, der von vornherein auf eine Pluralität hinangelegt ist. Aber auch darfür gilt: Es ist der eine unteilbare Glaube, der sich in verschiedener Hinsicht artikuliert.

16.Sauter (2011:252-253) gebruik die metafoor konstellasie om die eenheid van die geloofsuitspraak oor God en sy handeling in Jesus en dus ook die interafhanklikheid van die uitbreidings in die tweede artikel van die Apostolicum te verduidelik, maar van die uitbreidings in die tweede artikel van die Apostolicum te verduidelik, maar
waarsku dan in dieselfde asem dat die metafoor nie skematisme in die hand moet werk nie. 
hulle hoop gee (1 Pet 3:15). ${ }^{17}$ Geloofsbelydenis is daarom nie die nasegging van kontekslose algemene waarhede nie, maar rekenskap oor ons hoop as gelowiges. In die lig hiervan word Jesus reeds in die Nuwe Testament met verskeie ander name of eretitels benoem naas Christus en Here. Deur meer eretitels aan Jesus toe te ken, word telkens opnuut bely wie $\mathrm{Hy}$ is. Omdat eretitels alleen egter nie altyd toereikend kan verduidelik wie Jesus is nie, is uit die staanspoor ook van geloofsformules (soos byvoorbeeld 1 Kor 15:3-5) gebruik gemaak om te verduidelik wie Hy is. Ebeling (1975a:258-260) toon aan dat die verskillende Christologiese skemas wat ons uit die dogmatiese oorlewering ken, daarop dui dat rekenskap oor Jesus aan die hand van belydenisse wat oor Hom afgelê word, produktief deur die eeue voortgesit is. Die ou kerklike Christologie verduidelik byvoorbeeld die verhouding tussen die twee nature van Christus met die stelling dat die tweede persoon van die Triniteit die menslike natuur in hipostatiese eenheid met die goddelike natuur opneem. Hierdie belydenisuitspraak vervul uit die staanspoor ook ' $n$ fundamentele hermeneutiese funksie in die uitleg van ander Christologiese uitsprake. Die Middeleeus-skolastiese Christologie neem die twee-nature-leer van die ou kerk oor, maar bou dit soteriologies uit deur op die satisfaktoriese betekenis van Christus se dood te fokus en 'n onderskeid tussen die persoon en die werk van Christus te tref. Die oud-Protestantse Christologie neem die leerstukke oor die persoon van Christus wesentlik onveranderd uit die skolastiek oor, maar struktureer die leer oor die werk van Christus in leerstukke oor die ampte. Verder word leerstukke oor die vernederde en verhoogde staat van Christus ingevoer.

Getrou aan sy uitgangspunt dat ons sake reg moet onderskei sonder om die samehang tussen die onderskeie sake op te skort, bely die wêreldburger Ebeling (1975a:260-261) in die skemeruur van die Westerse kultuur vanuit die Duitssprekende deel van Europa en teen die interpretasiehorison van God, die mensdom en die wêreld (Ebeling 1967d:432-436, 1975c:285, 290, 304-308, 1983b:62) Jesus as die Woord van God, die Broeder van die mense en die Heer van die wêreld. ${ }^{18}$

\section{Geloof alleen}

Reeds vroeg in sy loopbaan skryf Ebeling (1967a:49) dat waaksame besorgdheid wat daarop gemik is om die suiwerheid van die evangeliese verkondiging te beskerm deur na binne gerigte en afgrensende teologiebeoefening gevaar inhou:

Die gevare van 'n konsentrasiebeweging (afgrensende teologiebeoefening) is vanselfsprekend eensydigheid, verenging, afsondering, 'n strewe na beveiliging en onaanvegbaarheid,

17.'n Opmerking van Sauter (2011:247), Die Glaubenssprache wird durch die Bewegung im Glauben auf Hoffnung hin strukturiert, werp lig op die keuse om in hierdie verband na 1 Petrus 3:15, wat oor hoop handel, te verwys. 'n Opmerking van Ebeling (1963:36) werp ook lig op die saak: Denn der Glaube, der aus dieser
Christus-Botschaft empfangen wird, ist Teilname des Menschen an Gott im Warten auf ihn. Kyk ook na Beutel (2003:29).

18.Ebeling (1979b:497-547) wy 'n omvattende hoofstuk in die tweede band van sy Dogmatik des christlichenGlaubens aan hierdie temakompleks. 'n vlug weg van kritiese gesprekvoering en aanvegting af. ${ }^{19}$ (bl. 49; outeur se eie vertaling)

Slagspreukteologie is daarom vir hom net so onaanvaarbaar soos dogmatisme, tradisionalistiese konfessionalisme, klerikalisme, sakramentalisme, piëtistiese stigtelikheid, radikalisme of belydenisretoriek. Die spreuk sola fide (geloof alleen) kan dus; net soos die ander Reformatoriese uitdrukkings solus Christus (Christus alleen), sola gratia (genade alleen) en sola scriptura (die Skrif alleen); nie as 'n algemene teologiese slagspreuk gebruik word los van die polemiese konteks waarbinne dit aanvanklik gebruik is of van die teologiese verwysingsraamwerk waarbinne dit ontstaan het nie (Hauck \& Schwinge 1982:189; Hauschild 1999:289-290). ${ }^{20}$

In aansluiting by Luther meen Ebeling (2006a:178-181) dat geloof, spesifiek die sola fide van die Reformatoriese geloofsverstaan, alleen met verwysing na liefde, maar dan ook onderskeie van liefde, bevredigend beskryf kan word. Om sowel die samehang as die onderlinge spanning tussen geloof en liefde in die visier te kry, moet dit in terme van die regverdigingstema bespreek word. Ebeling (1979a:32, 2006a:185) meen dat Luther se benadering tot die saak, waarin hy Luther ook volg, nie op ' $n$ temaverskuiwing dui nie, maar eerder op ' $n$ toespitsing daarvan (eine Themapräzisierung), want alleen op grond van die regverdigingsleer kan die noodwendigheid van die samehang en die onderskeid tussen geloof en liefde begryp word.

Geloof skep die moontlikheid om lief te kan kry (Ebeling 2006a:187-189). Geloof is God se werk in ons wat ons verander om opnuut gehoorsaam aan Hom te wees. Geloof kom nie uit die mens self tot stand nie, maar is 'n geskenk van God (Ebeling 1989:441, 445, 447). Geloof is egter nie net 'n sedelike kragtoevoer tot die mens wat die mens in staat stel om goed te doen nie, maar bewerk ' $n$ radikale vernuwing van die mens - 'n wedergeboorte, 'n afsterwe van die ou mens en 'n opstanding van die nuwe mens. Hier vind nie ' $n$ verandering aan 'n mens plaas nie, maar die persoon self word wesentlik verander (Gal 2:20). Ek, as sondaarmens, moet my eie persoon prysgee om Christus voortdurend voor oё te hou. In geloof word uit die mens en Christus 'n nuwe persoon gebore, in die sin dat niks weer tussen die gelowige en Christus in die gelowige skeiding kan bring nie.

Geloof is die vervulling van die eerste gebod. Daarom vorm dit die basis van alle ander goeie werke - werke van liefde (Ebeling 1971a:306, 1983g:3, 2006a:190-194). Geloof, as dryfkrag vir handeling, skep nie goeie werke nie, maar geloof

19 Die Gefahren einer Konzentrationsbewegung sind natur gemä $\beta$ die der Vereinseitigung, Verengung und Abkapselung, eines Strebens nach Sicherung und Unangreifbarkeit, einer Flucht vor der Auseinandersetzung und Anfechtung.

20 Ricoeur (2006:82) verduidelik die saak treffend: Wenn Luther sagt »allein durch den Glauben", sola fide, äussert er nicht etwa ein moralisches oder gar ein Lebensprinzip, sondern vielmehr ein hermeneutisches Prinzip. Denn das sola fide, uallein durch den Glauben ", schliesst jede andere Mediation aus als die des Wortes, "allein durch den Glauben", schliesst jede andere Mediation aus als die des Wortes, das in einer lebendigen Aktualität ausgelegt wird. Das sola fide bedeutet, dass das einmalige Geschehen allein gegenwärtig wird durch ein anderes, ihm homogenes Geschehen, und dieses nämlich ist ein anderes Wortgeschehen.... Einzig in diese Verbindung zwischen einem Wortgeschehen und einem anderen Wort, das dieses auslegt, ist eine Kirchengeschichte möglich, wird Geschichte geschaffen. Die Kirche des Wortes hat keine andere Sicherheit als eine ständige Exegese ... 
as die mag om die goeie te bewerk, skep goeie werke. Wat Ebeling met hierdie formulering wil benadruk, is dat geloof ' $n$ goeie gewete voor God tot stand bring, en alleen waar ' $n$ mens se gewete voor God bevry is, is jy ook bevry van die dwang om jouself te probeer regverdig, en daar word jy dan ook bevry om die goeie te doen, naamlik dade van liefde waarin jy jouself prysgee in liefde vir ander. Waar nie geloof is nie, bestaan nie ' $n$ goeie gewete voor God nie, en daar is liefde as selfprysgawe ook nie moontlik nie (Ebeling 1969a:174; Schlögel 1988:90).

Sola fide is 'n stryd om reine liefde. Geloof werk deur liefde op so ' $n$ wyse dat liefde die instrument is waardeur geloof werk en liefde daarom nie selfstandig as die oorsaak van goeie werke verstaan kan word nie (Ebeling 1981:333, 2006a:196). In geloof alleen word ons regverdig voor God en in geloof alleen word ons bevry om lief te hê.

\section{Geloof en godsdiens}

Soms word na die Christendom verwys as die religio vera, die ware godsdiens. Hiermee word die Christendom tot die absolute en enigste ware godsdiens verhef. Ebeling (1979a:135) vra wat dit is wat die Christendom waar maak. Omdat die Christendom ' $n$ komplekse verskynsel is waarin baie religieuse fenomene saamkom en wat boonop met verloop van tyd van gesig verander het, kan 'n enkele fenomeen of ' $n$ konglomeraat van meer fenomene nie as die waarmakende aspek of aspekte van die Christendom uitgelig word nie. Wat die Christendom waar maak, is dít wat met die kategorie evangelie beskryf word. Die evangelie kan nie sonder meer in een bepaalde kerugmatiese formule of in ' $n$ geloofsbelydenis vasgevang word nie. Die evangelie het altyd betrekking op Jesus Christus. Daarom is die waarheid van die Christendom 'n waarheid ekstern tot die Christendom. Die Christendom kan net waar wees in die mate wat dit op Christus betrekking het en in terme van Christus gerelativeer word. Jesus sê: 'Ek is die waarheid' (Joh 14:6) en nie net 'Ek het die waarheid' of 'Ek leer die waarheid' nie. Die ware in die Christendom is geloof (Ebeling 1979a:136). Geloof vind egter nie sekerheid in die geloof self nie, maar vind dit buite die geloof in die grond daarvan. Die sekerheid van die geloof is nie die selfversekerdheid van die gelowige nie, maar 'n verplasing van mense om buite hulleself sekerheid te vind daarin dat God hulle aangeneem en liefgekry het. Ebeling meen dat die Christendom met hierdie benadering nie die waarheid prysgee nie, maar dit reeds ernstig laat geld.

Beteken dit nou dat geloof en waarheid net binne die domein wat as Christelik geld, gevind kan word? Ebeling (1979a:136) benader die vraagstuk versigtig deur die woorde van Jesus oor die heidense centurion soos berig in Matteus 8:10 as vertrekpunt te neem: 'Amen, ${ }^{21}$ Ek sê vir julle, by niemand in Israel het ek so 'n groot geloof gevind nie'. In die lig van hierdie uitspraak van Jesus is Ebeling se vraag: Wat gee ons die reg daartoe om die vrede en die vryheid wat God skenk,

21. Hier behoort ons in ag te neem dat Ebeling ([1958] 1967c:244) groot waarde aan die amen-uitsprake uit die mond van Jesus toeken, omdat hy oortuig is dat Jesus die amen-uitsprake uit die mond van Jesus toeken, omdat hy oortuig is dat Jesus
Hom gans en al aan God prysgee met dié uitsprake wat Hy maak, in die sin dat die uitsprake met God se werklikheid ooreenstem. die troos wat Hy bied en die sekerheid van sy liefde te wil beperk tot mense wat die Christelike geloof aanhang?

Die uitsonderlike van die evangelie is juis daarin te vind dat dit godsdiens soos wat dit in die onderskeie godsdienste uitdrukking vind, relativeer (Ebeling 1979a:137). 'Daar is nie Jood of Griek nie ... want julle almal is een in Christus Jesus' (Gal3:28). In die godsdiensgeskiedenis was hierdie standpunt onbekend totdat Paulus dit geuiter het. Dit is welbekend dat groot verdraagsaamheid in die Hellenistiese wêreld tussen die onderskeie kultusse bestaan het. Selfs die keiserkultus het konkurrente kultusse geduld. Tog verwerp die Christendom met beslistheid alle ander kultusse deur die evangelie en slegs die evangelie die maatstaf te maak wat aan jou verhouding met God gestalte kan gee. In hierdie opsig is 'n kritiese benadering tot alle vorms van godsdiens uit die staanspoor ' $n$ integrale deel van die evangelieverkondiging van die kerk. Die evangelie staan in spanning met godsdiens, tog vind dit vernaamlik, maar nie uitsluitlik nie, uitdrukking in terme van godsdienstige gestaltegewing.

\section{Geloof en lewe}

Ebeling (1979a:105) is oortuig daarvan dat geloof en lewe in 'n onlosmaaklike resiproke verhouding tot mekaar staan. Hy meen verder dat Paul Tillich (1978:59-66) se metode van korrelasie, naamlik dat die lewe vrae aan 'n mens opdring waarop geloof die antwoorde verskaf, nie reg laat geskied aan die kompleksiteit van die verhouding tussen lewe en geloof nie. Ebeling (1979a:106-110, 1983f:85) wil daarom rekenskap gee van sowel die plek van geloof in die lewe as van die plek van die lewe in geloof. Hy meen dit is ontoereikend om, soos wat alte dikwels in die dogmatiek gedoen word, geloof te wil beskryf as 'n geestelike vermoë van die mens wat in die intellek of die wil van die mens gelokaliseer word. Ebeling (1979a:107) laat hom deur Schleiermacher lei, wat nie geloof in die wete of doen van die mens probeer lokaliseer nie, maar wel in die gewaarwordingsvermoë (Gefühl) wat vir kennis en handeling konstitutief is. Hy kies, getrou aan Luther, die begrip gewete om die antropologiese oordsbepaling van geloof aan te dui. Ebeling (1967b:404, 1979a:107) verstaan gewete as dít waarop die persoonwees van die mens self gerig is en as dít waarin die lewe as 'n geheel uitdrukking vind (Ebeling 1971a:304, 1983a:46, 1989:453,22 1991:384, 390). Gewete is dít waarin die mens se eksterne gerigtheid gesetel is (Ebeling 1967d:443, 1983b:72, 1989:465). Dit rig 'n mens op die aansprake wat op jou gemaak word sowel as op die feit dat jy gehoor word, en dit bied aan jou die vermoë om oor jou eie lewe en die waarheid te kan oordeel en rekenskap te kan gee.

Waar die lewe self problematies word, kom geloof ter sprake. Waar die grond, sin of doel van die lewe bevraagteken word, of waar mense se identiteit of vryheid bedreig word, kom geloof ter sprake, want in hierdie situasies smag ' $n$ mens na meer as die onmiddellik voorhande situasie. 'n Mens smag

22.In hierdie vier tekste verwys Ebeling ook na Luther se gebruik van die begrip 'hart' om die oord aan te dui waar mense in die wese van hulle bestaan as persoon deur die Woord van God aangespreek word op'n wyse dat' $n$ antwoord nodig is. 
na die transendente. Geloof is protes teen die lewe wat voorhande is ten gunste van die ware lewe (Ebeling 1979a:108). ${ }^{23}$

Die mens kom in geloof tot rus, want in geloof kom mense tuis en vind hulle geborgenheid (Ebeling 1967c:216, 1979a:109). Geloof het altyd betrekking op lewe, en omgekeerd is lewe niks anders nie as lewe wat geglo word (Ebeling 1981:209, 1983b:77). Geloof en lewe hoort ten nouste saam. Die Bybel benadruk ook hierdie verband: 'Hy wat in die Seun glo, het die ewige lewe' (Joh 3:36) en 'die geregverdigde uit geloof, sal lewe' (Rom 1:17; Gal 3:11, aangehaal uit Hab 2:4). Daarom is God nie die God van dooies nie, maar van lewendes (Matt 22:32). Die lewe wat geglo word, is die ewige lewe wat reeds in geloof begin aanbreek het. Geloof kan daarom vir Ebeling (1975c:298) niks anders beteken nie as opstandingsgeloof. ${ }^{24}$ Hy verstaan die Bybelse oortuiging dat ' $n$ mens nie van brood alleen kan lewe nie (Deut 8:3; Matt 4:4), radikaal in die sin dat ons naas brood en water ook die water van die lewe, die brood van die lewe, die lig van die lewe en die woord van lewe nodig het om waarlik te lewe.

Die Nuwe Testament leer ons om radikaal nuut oor die lewe te dink. Lewe is nie in ' $n$ mens self te vind nie (Ebeling 1967c:216), maar buite jouself in Christus. Daarom lewe gelowiges nie vir hulleself nie, maar vir Christus. Dit impliseer dat Christus in die gelowige is en die gelowige in Christus. Deelname aan die nuwe lewe beteken om deel te neem aan die nuwe lewe van Christus, die opgestane Here (Ebeling 1989:145). Ebeling (1979a:110) meen dat 'n fundamentele onderskeiding ook hier ter sprake kom verlore lewe en ewige lewe moet onderskei word. Wanneer die Christelike geloof nie meer rekenskap kan gee van wat met ewige lewe bedoel word en hoe die ewige lewe in Jesus teenwoordig geword het nie, kan die saak van die Christelike geloof nie verdedig word nie.

\section{Geloof en denke}

Ebeling (1979a:152-156, 1983f:87) meen dat daar spanning en selfs konflik tussen geloof en rede (Vernunft) bestaan. Daar heers egter dikwels misverstand oor die aard van die konflik, met die gevolg dat die een of ander skynkonflik, eerder as die werklike konflik, aan ons voorgehou word. Ebeling beskryf drie sulke skynkonflikte wat opgehaal word as sou dit die konflik tussen geloof en rede reg beskryf. 'n Positivistiese skynkonflik ontstaan wanneer 'n positivistiese begrip van redelikheid as vertrekpunt geneem word. Wanneer redelikheid ingeperk word deur alleen die empiries aantoonbare as werklikheid te veronderstel, reageer sommige gelowiges deur geloof op enkele openbarings-positivistiese

23.Ebeling (1997:482) vind aansluiting by die werklikheidsgetrouneid van Luther se pastorale teologie. Soos Luther dink hy in terme van die spanning wat altyd tussen die massa perditionis, die gesiglose sondige mensemassa, en die enkeling bestaan. Binne hierdie spanning moet geloof standhou. Elders (Ebeling [1981] 1983f:82) ste hy dat geloof omring word deur feite, indrukke, prognoses en angste - alles mpulse uit die harde werklikheid. Geloof bestaan te midde van egte konflikt waarmee mense in hulle diepte wese, in die hart of die gewete, gekonfrontee
word.

24.In hierdie opsig deel Ebeling 'n oortuiging van sowel Barth as Bultmann (Van Wyk 2013:2). feite te wil baseer wat in konkurrensie met die toepaslike natuurwetenskaplike feite staan. 'n Rasionalistiese skynkonflik is nou verwant aan die positivistiese skynkonflik. In hierdie geval werk ' $n$ verengde begrip van redelikheid ' $n$ gedeeltelike werklikheidsblindheid in die hand. Geloof word dan daarvan verdink dat dit 'n gebrekkige ervaringsbasis het. Tradisionele geloof word afgemaak as die aanvaarding van ' $n$ aantal leerstukke sonder enige ervaringsbasis, en teologie word gered deur in ' $n$ verligte gewaad as rasionalistiese teologie te opereer. Ebeling verwys in die derde plek ook na 'n irrasionalistiese skynkonflik. In hierdie geval word ' $n$ verkeerde begrip van geloof as vertrekpunt geneem. Geloof word as onredelik en bygelowig getakseer: credo quia absurdum (ek glo, omdat dit van die normale afwyk [onredelik is]; dus, ek glo in teenspraak met redelikheid). Die formele outoriteite wat met betrekking tot geloof ter sprake kom, eis van die gelowiges 'n sacrificium intellectus (opoffering [van die] verstand). Geloof het alleen 'n plek waar aan die irrasionele ruimte gegun word. Verder moet geloof immuniteit opbou teen die aanslae van die rede. Die gemeenskaplike in al die skynkonflikte is dat, volgens die oordeel van die rede, geloof onredelik is en dat, volgens die oordeel van die geloof, redelikheid ongelowig is. Ebeling (1979a:155) is egter daarvan oortuig dat redelikheid nie geloof bedreig nie en dat geloof ook nie redelikheid bedreig nie. Redelikheid moet eerder deurlopend teen onredelikheid waak, en net so moet geloof gedurig teen ongeloof weerstand bied (Ebeling 1967b:400-401). In die naam van redelikheid word baie onredelike dinge gedoen, ${ }^{25}$ en in die naam van geloof gedy ongeloof soms.

Ebeling (1979a:156) is oortuig daarvan dat die egte konflik tussen geloof en rede te make het met die werklikheid dat redelikheid in ons verligte samelewing verstaan word as die hoogste vorm van menslike selfbevestiging en dat geloof nie anders kan nie as om die werklikheid van die rede se opperheerskappy in die lewe van mense as sonde te beskryf. Verder vra geloof van 'n mens dat jy die heilsverwagtinge wat jy van die rede koester, moet prysgee om jou gewete te laat aanspreek deur die evangelie en in alleen afhanklikheid van God se genade te lewe. Redelikheid, gedryf deur die onredelike aanspraak om absoluut te geld, dompel mense voortdurend in teenspraak met die ideale van menswees. Die realiteit van hierdie teensprake dui aan dat sonde nie net 'n redelike moontlikheid is nie, maar ' $\mathrm{n}$ werklikheid. Die animal rationale (redelike wese) is die homo peccator (sondige mens). Die verlange om die haglike situasie waarin die mens en die wêreld vasgevang is wesentlik te verander, kan nie deur redelike menslike handeling alleen vervul word nie, maar in geloof, deur genade, is hoop op heil redelik en bly dit lewend. 'n Mens glo eers werklik wanneer jy jou toekoms van God verwag, want God is die God wat kom. Geloof is sekerheid oor die toekoms wat God bring (Ebeling 1967c:218, 247, 1989:147).

25.Ebeling (1982:468-469) formuleer in terme van die rede die saak treffend: Eben der Mensch, der sich selbst der ratio rühmt und sie als das spezifisch menschliche Lebensprinzip in Anspruch nimmt, erweist sich angesichts des Lebens in dessen äußerstem Ernst als blind und taub, als hätte er weder Vernunft noch Leben. 


\section{Beoordeling}

Met die woorde 'Ebeling was 'n evangeliese doktor van die kerk $^{\prime 26}$ beskryf Jüngel (2001:1) die leidende rol wat Ebeling nie alleen as leermeester van verskeie teologiese studente gespeel het nie, maar ook as leermeester van die kerk. Beutel (2012a:538) sluit sy omvattende Ebeling-biografie af met die woorde van die titel van Ebeling se afskeidslesing in Tübingen: "n Lewe vir die teologie - 'n teologie vir die lewe ${ }^{\prime 27}$ en dui só die belang aan van Ebeling se lewensbydrae tot die teologie (kyk ook na Beutel 2003:41). Ebeling wou egter met sy teologie niks anders doen as om die viva vox evangelii (lewende stem van die evangelie) te dien nie. 'n Mens kan nie anders met God omgaan, stel Ebeling (2006b:71) in aansluiting by Luther, as deur sy woord van belofte te glo nie en teologie dien dié geloof (kyk ook na Bühler 2006b:71). Geloof is dus saam met die Woord van God die oorkoepelende tema van Ebeling se teologie (Bühler 2006a:3; Werbick 2012:1). Ebeling se diagnose dat die funksieverlies van die Christelike geloof in die eietydse samelewing veral met die onvermoë van die Christelike getuies te make het om hulle geloof in lewendige en lewensskeppende verstaanbare taal onder woorde te bring, dui aan dat gelowiges meer as ooit te vore met oortuiging rekenskap oor geloof moet aflê (Beutel 2003:29, 38, 2012b:1; Knauer 1969:3, 1984:iii). Vanuit hierdie oogpunt is Ebeling se fokus op die geloofstema as die struktuurskeppende uitgangspunt van sy teologie verstaanbaar.

Ebeling se besinning oor geloof is in sommige kringe met agterdog en skeptisisme begroet. Kritiek teen Ebeling wissel van die een uiterste, naamlik dat hy hom in die laer van die Lutherse konfessionaliste sou bevind, tot die ander uiterste, naamlikdatsy teologieniks andersas gevaarlikeBultmanianisme sou wees nie. Hy sou selfs ' $n$ pseudo-Luther ontwerp om sy pseudogeloof te dien (kyk na Beutel 2006:325). Ebeling word ook betrek by generiese kritiek teen teologie wat uitsluitlik Woordverkondiging as medium van geloofskommunikasie handhaaf (so byvoorbeeld Pilnei 2007:375-376). Pilnei meen dat godsdienstige biografie, godsdiensopvoeding, pastorale handelinge en die konfrontasie met sekulêre insigte in verband met die geestelike werklikheid ook geloof kan bevorder. Dit is te betwyfel of hierdie soort kritiek werklik die wese van Ebeling se geloofsverstaan tref. Die mees substansiële voorbehoud, nie alleen met betrekking tot Ebeling se geloofsverstaan nie, maar met betrekking tot sy teologie as sodanig en die vertrekpunt daarvan, word soos volg deur Werbick (2012) opgesom:

Dat die duidelikheid van onderskeiding die fakties werksame bemiddelingsamehange nie meer tot tema maak nie, want dit kan nie eenvoudig deur onderskeiding uit spel geplaas word nie, is die kritiek wat veral sedert 1968 teen Ebeling ingebring is. ${ }^{28}$ (bl. 3; outeur se eie)

Ebeling (1988) het homself alreeds in hierdie verband grondig verantwoord. Gerhard Ebeling se teologie kan met vrug gebruik word om ons eie geloofsbesinning te verryk.

26. Ebeling war ein evangelischer doctor ecclesiae.

27. Ein Leben für die Theologie - eine Theologie für das Leben.

28.Dass die Klarheit der Unterscheidungen die faktisch wirksamen Vermittlungszusammenhänge nicht mehr thematisiert, die sich durch Vermittlungszusammenhänge nicht mehr thematisiert, die sich durch
Unterscheidungen ja nicht einfach außer Kraft setzen lassen, das ist die Kritik Unterscheidungen ja nicht einfach außer Kraft setzen lassen, das ist die
gewesen, die Ebeling sich vorallem seit den 1968 er Jahren zugezogen hat.

\section{Erkenning Mededingende belange}

Die outeur verklaar hiermee dat hy geen finansiële of persoonlike verbintenis het met enige party wat hom nadelig of voordelig kon beïnvloed het in die skryf van hierdie artikel nie.

\section{Literatuurverwysings}

Beutel, A., 2003, 'Rechenschaftüber den Glauben: Grundzugund Leitmotiv der Theologie bei Gerhard Ebeling', in P. Stoellger \& A. Mauz (Hg.), Gerhard Ebeling, S. pp. 26-41, besigtig op 17 Julie 2015, by http://www.hermes.uzh.ch/publikationen/ pp. 26-41, besigtig op 17Julie 2015, by http://ww
Hermeneutische-Blaetter/HBI2003_Ebeling.pdf

Beutel, A., 2006, 'Nachwort', in G. Ebeling (Hg.), Luther: Einführung in sein Denken, 5. Aufl., S. pp. 311-333, J.C.B. Mohr (Paul Siebeck), Tübingen.

Beutel, A., 2010, 'Theologie als Unterscheidungslehre', in A. Beutel (Hg.), Luther Handbuch, 2. Aufl., S. pp. 450-454, J.C.B. Mohr (Paul Siebeck), Tübingen.

Beutel, A., 2012a, Gerhard Ebeling: Eine Biographie, J.C.B. Mohr (Paul Siebeck), Tübingen.

Beutel, A., 2012b, 'Theologe Gerhard Ebeling: Rechenschaftüber den Glaubenablegen', Neue Zürcher Zeitung, besigtig op 9 Julie 2015, by http://www.nzz.ch/ rechenschaft-ueber-den-glauben-ablegen-1.17326417

Bühler, P., 2006a, 'Vorwort', in G. Ebeling (Hg.), Mein theologischer Weg, S. 2-3, besigtig op 17 Julie 2015, by http://www.hermes.uzh.ch/publikationen/ Hermeneutische-Blaetter/HB2006_Ebeling.pdf

Bühler, P., 2006b, 'Zur geplanten Fortsetzung des Textes: Ein Nachwort', in G. Ebeling (Hg.), Mein theologischer Weg S. 68-74, besigtig op 17 Julie 2015, by http://www. hermes.uzh.ch/publikationen/Hermeneutische-Blaetter/HB2006_Ebeling.pdf

Bultmann, R., 1968, 's.v. rírtıs', in G. Kittel (Hg.), Theologisches Wörterbuch zum Neuen Testament, 6. Bd., S. 174-228, W. Kohlhammer Verlag, Stuttgart.

Ebeling, G., 1963, Vom Gebet, J.C.B. Mohr (Paul Siebeck), Tübingen.

Ebeling, G., 1967a, 'Die Bedeutung der historisch-kritischen Methode für die protestantische Theologie und Kirche', in G. Ebeling (Hg.), Wort und Glaube, 1 Bd., 3. Aufl., S. 1-49, J.C.B. Mohr (Paul Siebeck), Tübingen.

Ebeling, G., 1967b, 'Glaube und Unglaube im Streit um die Wirklichkeit', in G. Ebeling (Hg.), Wort und Glaube, 1. Bd., 3. Aufl., S. 393-406, J.C.B. Mohr (Paul Siebeck), Tübingen.

Ebeling, G., 1967c, 'Jesus und Glaube', in G. Ebeling (Hg.), Wort und Glaube, 1. Bd., 3. Aufl., S. 203-254, J.C.B. Mohr (Paul Siebeck), Tübingen.

Ebeling, G., 1967d, 'Theologische Erwägungen über das Gewissen', in G. Ebeling (Hg.), Wort und Glaube, 1. Bd., 3. Aufl., S. 429-446, J.C.B. Mohr (Paul Siebeck), Tübingen.

Ebeling, G., 1969a, 'Gewissheit und Zweifel: Die Situation des Glaubens im Zeitalter nach Luther und Descartes', in G. Ebeling (Hg.), Wort undGlaube, 2. Bd., S. 138183, J.C.B. Mohr (Paul Siebeck), Tübingen.

Ebeling, G., 1969b, 'Verantworten des Glaubens in Begegnung mit dem Denken M Heideggers: Thesen zumVerhältnis von Philosophie und Theologie', in G. Ebeling (Hg.), Wort und Glaube, 2. Bd., S. 92-98, J.C.B. Mohr (Paul Siebeck), Tübingen.

Ebeling, G., 1971a, 'Luthers Glaubensverständnis: Vergangenheit oder Zukunft?', in G. Ebeling (Hg.), Lutherstudien, 1. Bd., S. 302-307, J.C.B. Mohr (Paul Siebeck), Tübingen.

Ebeling, G., 1971b, 'Frei aus Glauben: Das Vermächtnis der Reformation', in G. Ebeling (Hg.), Lutherstudien, 1. Bd., S. 308-329, J.C.B. Mohr (Paul Siebeck), Tübingen.

Ebeling, G., 1975a, 'Der Aussagezusammenhang des Glaubens an Jesus', in G. Ebeling (Hg.), Wort und Glaube, Beiträge zur Fundamentaltheologie, Soteriologie und Ekklesiologie, 3. Bd., S. 246-269, J.C.B. Mohr (Paul Siebeck), Tübingen.

Ebeling, G., 1975b, 'Was heisst Glauben?', in G. Ebeling (Hg.), Wort und Glaube, Beiträge zur Fundamentaltheologie, Soteriologie und Ekklesiologie, 3. Bd., S. 225235, J.C.B. Mohr (Paul Siebeck), Tübingen.

Ebeling, G., 1975c, 'Was heisst: Ich glaube an Jesus Christus?', in G. Ebeling (Hg.), Wort und Glaube, Beiträge zur Fundamentaltheologie, Soteriologie und Ekklesiologie, 3. Bd. S. 270-308, J.C.B. Mohr (Paul Siebeck), Tübingen.

Ebeling, G., 1975d, 'Zwei Glaubensweisen?', in G. Ebeling (Hg.), Wort und Glaube, Beiträge zur Fundamentaltheologie, Soteriologie und Ekklesiologie, 3. Bd., S. 236245, J.C.B. Mohr (Paul Siebeck), Tübingen.

Ebeling, G., 1979a, Dogmatik des christlichen Glaubens, 1. Bd., J.C.B. Mohr (Paul Siebeck), Tübingen.

Ebeling, G., 1979b, Dogmatik des christlichen Glaubens, 2. Bd., J.C.B. Mohr (Pau Siebeck), Tübingen.

Ebeling, G., 1981, Die Wahrheit des Evangeliums: Eine Lesehilfe zum Galaterbrief, J.C.B. Mohr (Paul Siebeck), Tübingen.

Ebeling, G., 1982, Lutherstudien, 2. Bd.,Disputatio de Homine, 2. Teil, Die philosophische Definition des Menschen. Kommentar zu These 1-19, J.C.B. Mohr (Paul Siebeck), Tübingen.

Ebeling, G., 1983a, 'Erneuerung aus der Bibel', in G. Ebeling (Hg.), Umgang mit Luther S. 39-58, J.C.B. Mohr (Paul Siebeck), Tübingen.

Ebeling, G., 1983b, 'Schrift und Erfahrung als Quelletheologischer Aussagen', in G. Ebeling (Hg.), Umgang mit Luther, S. 59-81, J.C.B. Mohr (Paul Siebeck), Tübingen. 
Ebeling, G., 1983c, 'Theologisches Verantworten des Politischen: Luthers Unterrichtung der Gewissen heute bedacht', in G. Ebeling ( $\mathrm{Hg}$ ), Umgang mit Unterrichtung der Gewissen heute bedacht', in G. Ebe
Luther, S. 164-201, J.C.B. Mohr (Paul Siebeck), Tübingen.

Ebeling, G., 1983d, 'Die Toleranz Gottes und die Toleranz der Vernunft', in G. Ebeling (Hg.), Umgang mit Luther, S. 101-130, J.C.B. Mohr (Paul Siebeck), Tübingen.

Ebeling, G., 1983e, 'Usus politicus legis - usus politicus evangelii', in G. Ebeling (Hg.), Umgang mit Luther, S. 131-163, J.C.B. Mohr (Paul Siebeck), Tübingen.

Ebeling, G., 1983f, 'Von der Wahrheit des Glaubens', in G. Ebeling (Hg.), Umgang mit Luther, S. 82-94, J.C.B. Mohr (Paul Siebeck), Tübingen.

Ebeling, G., 1983g, 'Was Luther mir bedeutet', in G. Ebeling (Hg.), Umgang mit Luther, S. 1-7, J.C.B. Mohr (Paul Siebeck), Tübingen.

Ebeling, G., 1988, 'Das rechte Unterscheiden: Luthers Anleitung zu theologischer Urteilskraft', Zeitschrift für Theologie und Kirche 85(2), 219-258.

Ebeling, G., 1989, Lutherstudien, 2. Bd.,Disputatio de Homine, 3. Teil, Die theologische Definition des Menschen. Kommentar zu These 20-40, J.C.B. Mohr (Paul Siebeck), Tübingen.

Ebeling, G., 1991, Evangelische Evangelienauslegung: Eine Untersuchung zu Luthers Hermeneutik, 3. Aufl., J.C.B. Mohr (Paul Siebeck), Tübingen.

Ebeling, G., 1995, Predigten eines »llligalen« aus den Jahren 1939-1945, J.C.B. Mohr (Paul Siebeck), Tübingen.

Ebeling, G., 1997, Luthers Seelsorge: Theologie in der Vielfalt der Lebenssituationen an seinen Briefen dargestellt, J.C.B. Mohr (Paul Siebeck), Tübingen.

Ebeling, G., 2006a, Luthe: Einführung in sein Denken. Miteinem Nachwort von Albrecht Beutel, 5. Aufl., J.C.B. Mohr (Paul Siebeck), Tübingen.

Ebeling, G., 2006b, Mein theologischer Weg, besigtig op 17 Julie 2015, by http://www. hermes.uzh.ch/publikationen/Hermeneutische-Blaetter/HB2006_Ebeling.pdf

Ebeling, G., 2012, Studium der Theologie: Eine enzyklopädische Orientierung, 2. Aufl., J.C.B. Mohr (Paul Siebeck), Tübingen.

Hauck, F. \& Schwinge, G., 1982, Theologisches Fach- und Frendwörterbuch, Vandenhoeck \& Ruprecht, Göttingen.

Hauschild, W-D., 1999, Leherbuch der Kirchen- und Dogmengeschichte, 2. $B d$., Reformation und Neuzeit, GüterloherVerlagshaus, Gütersloh.

Hempelmann, H., 2013, 'Was heißt "christlicher Glaube"?: Reflexionen über einen ebenso notwendigen wie unmöglichen Begriff', Theologische Beiträge 44, 185-201.

Jüngel, E., 2001, Doctor ecclesiae: ZumTode des Theologen Gerhard Ebeling besigtig op 17 Julie 2015, by http://www.kirchen.ch/pressespiegel/ nzz/2001100265.pdf
Knauer, P., 1969, Verantwortung des Glaubens: Ein Gespräch mit Gerhard Ebeling aus katholischer Sicht, Josef Knecht, Fankfurt am Main.

Knauer, P., 1984, Zu Gerhard Ebelings 'Dogmatik des christelichen Glaubens'. 'Fundamentalunterscheidung' und 'Lebensbezug' als theologische Grundkategorien, besigtig op 9 Julie 2015, by http://peter-knauer.de/40.html

Luther, M., [1520] 1983, Von der Freiheit eines Christenmenschen, 6. Aufl., Gütersloher Verlagshaus, Gerd Mohn.

Luther, M., [1529] 1985, Der Große und der Kleine Katechismus, 2. Aufl., Vandenhoeck \& Ruprecht, Göttingen.

Pilnei, O., 2007, Wie entsteht christlicher Glaube?: Untersuchungen zur Glaubenskonstitution in der hermeneutischen Theologie bei Rudolf Bultmann, Ernst Fuchs und Gerhard Ebeling, J.C.B. Mohr (Paul Siebeck), Tübingen.

Ricoeur, P., 2006, 'Gerhard Ebeling: Rückwendung zur Reformation und Wortgeschehen', in G. Ebeling (Hg.), Mein theologischer Weg, S. 75-94, besigtig op 17 Julie 2015, by http://www.hermes.uzh.ch/publikationen/HermeneutischeBlaetter/HB2006_Ebeling.pdf

Sauter, G., 2011, Das verborgene Leben: Eine theologische Antropologie, Gütersloher Verlagshaus, Gütersloh.

Schlögel, H., 1988, DerMensch ist Gewissen .... Überlegungen zum Gewissenverständnis von Gerhard Ebeling, besigtig op 9 Julie 2015, by http://epub.uni-regensburg. de/8880/1/ubr03558_ocr.pdf

Schlögel, H., 1992, Nichtmoralisch, sondern theologisch: zum Gewissensverständnis von Gerhard Ebeling, Matthias Grünewald Verl., Mainz.

Tillich, P., 1978, Systematic theology, part I, reason \& revelation, SCM Press, London.

Van Staden, P., 2015, 'Christus ongedaan: 'n Evaluering van die betekenisverlies van die term gesalfde', LitNet Akademies 12(3), ISSN 1995-5928, besigtig op 7 Desember 2015, by http://www.litnet.co.za/christus-ongedaan-n-evaluering-vandie-betekenisverlies-van-die-term-gesalfde/

Van Wyk, G.M.J., 2012, 'Die mooi drome van burgerlike teologie verander toe in kerklike nagmerries', HTS Teologiese Studies/Theological Studies 68(1), Art. $\# 1338,12$ pages. http://dx.doi.org/10.4102/ hts.v68i1.1338

Van Wyk, G.M.J., 2013, 'Geloof in die opstanding van Jesus: Barth en Bultmann', HTS Teologiese Studies/Theological Studies 69(1), Art. \#1974, 10 pages. http:// dx.doi. org/10.4102/hts. v69i1.1974

Van Wyk, G.M.J., 2015, 'Rudolf Bultmann: Evangelie en geloof', HTS Teologiese Studies/Theological Studies 71(3), Art. \#3039, 9 pages. http://dx.doi.org/10.4102/ hts.v71i3.3039

Werbick, J., 2012, Wie Gottes Wort zu sprechen anfängt: Vor 100 Jahren wurde der bedeutende Theologe Gerhard Ebeling geboren, besigtig op 9 Julie 2015, by http://www.muenster.de/ angergun/werbick-ebeling100.pdf 